Ummi Sa'adah : The Effect Of Hatha Yoga on Dysmenorrhoea Pain in Adolescent Principle

\title{
THE EFFECT OF HATHA YOGA ON DYSMENORRHOEA PAIN IN ADOLESCENT PRINCIPLE
}

\author{
Ummi Sa'adah ${ }^{1}$, Kholisotin ${ }^{1}$, Zainal Munir ${ }^{1}$, Handono FR ${ }^{1}$, Abdul Hamid Wahid ${ }^{1}$ \\ Health faculty, Nurul Jadid University \\ Corresponding email: elaidahamas17@gmail.com
}

\begin{abstract}
Dysmenorrhea is pain during menstruation caused by muscle contraction and imbalance of the hormone progesterone in the blood. One of the non-pharmacological treatments is Hatha yoga therapy, which is a type of relaxation technique that can reduce pain intensity by relaxing skeletal muscles. This study was purposed to determine the effect of Hatha Yoga Therapy on Dysmenorrhoea Pain in Adolescents at Darul Falah Islamic Boarding School. The design of this study was the "Quasy experiment" study using "group non-equivalent controls" which were divided into experimental groups and control groups. The study was conducted at Darul Falah Islamic Boarding School, the number of 76 adolescents was taken using a simple random sampling technique. The measuring instrument used is the observation sheet. Hatha yoga intervention is carried out for 1 month with a frequency of 2 times for 40 minutes. The analysis used univariate and bivariate analysis using Mann Whitney and Wilcoxon. This study found a decrease in the intensity of dysmenorrhea pain in the experimental group after being given hatha yoga ( $\mathrm{p}$-value $0,000<\alpha 0,05)$ whereas in the control group P-value $=0,102(\mathrm{p}>0,05)$. The conclusion is that there is the influence of Hatha Yoga on the pain of dysmenorrhea in young women.
\end{abstract}

Keywords: Dysmenorrhea, hatha yoga.

\section{INTRODUCTION}

Adolescence is a period of transition from childhood to adulthood, which includes all developments and processes growing toward a maturity which includes mental, emotional, social and physical maturity experienced as preparation for adulthood. In addition to experiencing physical and emotional changes to normal female teenagers periodically, they will experience a reproductive system, namely menstruation. Menstruation is an overall condition of endometrial tissue due to the absence of mature eggs fertilized by sperm, the event is quite natural so that it can be ascertained that all normal women will experience this process (Handono et al., 2018). In some women, menstruation causes fear and worry when the menstrual pain arises. This condition is referred to as menstrual pain (dysmenorrhoea).

The incidence of dysmenorrhea in the world is very large. On average more than $50 \%$ of women in each country experience menstrual pain. In America, the percentage is around 60\%. The results of previous studies reported dysmenorrhoea in $90 \%$ of women aged less than 19 years and $67 \%$ of women aged 24 years (Bash, 2015). While in Indonesia it is estimated that 55\% of productive age women are tormented by pain during menstruation. Whereas in East Java the incidence (prevalence) of menstrual pain ranges from 45-95\% among women of productive age (Ruhi \& Meenal, 2014). 
Ummi Sa'adah : The Effect Of Hatha Yoga on Dysmenorrhoea Pain in Adolescent Principle

Dysmenorrhea is caused by muscle contraction. Cramps are felt in the lower abdomen radiating to the back or inner thigh surface (Marlinda, Rofli, 2013). Dysmenorrhea is divided into two, namely primary dysmenorrhoea and secondary dysmenorrhoea. Primary dysmenorrhea is pain during menstruation which is found without any pathological conditions of the pelvis, while secondary dysmenorrhoea is pain during menstruation caused by gynecological abnormalities (Aini et al., 2016).

Dysmenorrhea can be reduced pharmacologically and nonpharmacologically. One of them is the Hatha yoga movement. Hatha Yoga is a type of relaxation technique that can reduce pain intensity by relaxing skeletal muscles that experience spasm (Aisyiyah, 2017). The function or benefit of Hatha yoga is that it can help develop muscle and relax the stiff bones and muscles, where this movement stimulates the release of endorphin hormones that create a sense of comfort in the body and facilitate blood circulation so that it can overcome pain, especially dysmenorrhea (Pujiastuti Sindhu, 2009)

Hatha yoga sessions usually last 20 minutes to 1 hour (Kaszubski, 2004). In this study, Hatha yoga intervention was carried out for 1 month with a frequency of 2 times for 40 minutes. Hatha Yoga therapy is the choice of researchers because it is easy to do and does not require tools. Hatha Yoga therapy only involves the muscular system and respiration, does not need other tools so that it is easy to do anytime or at any time. Based on research conducted by Goncalves, Barros, \& Bahamonndes (2017) about Hatha Yoga as a treatment for pain in 2 (two) groups of women at the University of Campinas Medical School who experience dysmenorrhea due to endometriosis. The study was conducted 2 (two) times a week for 8 (eight) weeks. The results of the study showed that the average pain was significantly lower among women who practiced Hatha Yoga. (Inggriani, 2017). Based on the above background, a study was conducted to identify differences in the pain scale of primary dysmenorrhoea experienced by girls before and after in the control group and in the intervention group. To find out whether there is an effect of Hatha Yoga therapy on the pain of dysmenorrhea in young women.

\section{METHODS}

The design of this study was the "Quasy experiment" study using "group non-equivalent controls" which were divided into experimental groups and control groups. The study was conducted in January February 2019 at the Darul Falah Islamic Boarding School. The number of 76 respondents was taken using a simple random sampling technique. The measuring instrument used is the observation sheet. The action is carried out for 40 minutes in 1 day. The analysis used univariate and bivariate analysis using Mann Whitney and Wilcoxon. this study found a decrease in the intensity of dysmenorrhea pain in the 
Ummi Sa'adah : The Effect Of Hatha Yoga on Dysmenorrhoea Pain in Adolescent Principle

experimental group after being given yoga $(\mathrm{p}$-value $0,000<\alpha, 0,05)$ while in the control group P-value $=$ $0,102(\mathrm{p}>0,05)$.

\section{RESULTS}

Based on the research the results are as follows:

Table 1 Distribution of Respondents' Frequency by Age and Education

\begin{tabular}{cccccc}
\hline No. & Characteristics & \multicolumn{2}{c}{ Experimental group } & \multicolumn{2}{c}{ Control group } \\
\hline 1 & Age & $\mathrm{F}$ & $\%$ & $\mathrm{~F}$ & $\%$ \\
\hline & $12-15$ & 22 & 58 & 22 & 58 \\
\hline & $16-19$ & 16 & 42 & 16 & 42 \\
\hline total & 38 & 100 & 38 & 100 \\
\hline Education & & & & 34 \\
\hline & MTs & 13 & 34 & 13 & 66 \\
\hline MA & 25 & 66 & 25 & 100 \\
\hline
\end{tabular}

Based on table 1 above, it can be seen that the age characteristics of the respondents in the experimental group were mostly $12-15$ years old, namely 22 people (58\%), and the minority of respondents aged 16-19 years were 16 people (42\%). Whereas in the majority control group respondents aged 12-15 years were 22 people (58\%), and minorities aged 16-19 years were 16 people (42\%).

While the characteristics of respondents based on education can be seen that in the experimental group the majority of respondents at the MA level were as many as 25 people (66\%), and the minority education respondents were at the MTs level of 13 people (34\%). Whereas in the majority control group the education of respondents at the MA level was 25 people (66\%), and the minority education respondents were at the MTs level of 13 people (34\%). 
Ummi Sa'adah : The Effect Of Hatha Yoga on Dysmenorrhoea Pain in Adolescent Principle

Table 2 Distribution of $\mathbf{N}$ Scale Scale Before and After Hatha Therapy Yoga in the Experiment Group on Days 1 and 2

\begin{tabular}{|c|c|c|c|c|c|}
\hline \multirow[t]{3}{*}{ Day } & \multirow[t]{3}{*}{ Pain Scale } & \multicolumn{2}{|c|}{ Before } & \multicolumn{2}{|c|}{ After } \\
\hline & & \multicolumn{2}{|c|}{ Respondents } & \multicolumn{2}{|c|}{ Respondents } \\
\hline & & $\mathrm{F}$ & $\%$ & $\mathrm{~F}$ & $\%$ \\
\hline \multirow[t]{4}{*}{1} & No pain 0 & 0 & 0 & 0 & 0 \\
\hline & $\begin{array}{c}\text { Lightweight } \\
1-3\end{array}$ & 15 & 39.5 & 26 & 68.4 \\
\hline & Being 4-6 & 23 & 60.5 & 12 & 31.6 \\
\hline & total & 38 & 100 & 38 & 100 \\
\hline \multirow[t]{4}{*}{2} & No pain 0 & 0 & 0 & 5 & 13.2 \\
\hline & $\begin{array}{c}\text { Lightweight } \\
1-3\end{array}$ & 24 & 63.2 & 33 & 86.8 \\
\hline & Being 4-6 & 14 & 36.8 & 0 & 0 \\
\hline & total & 38 & 100 & 38 & 100 \\
\hline
\end{tabular}

Table 3 Distribution of Pain Scale Before and After Observation on Control Group on Days 1 and 2

\begin{tabular}{lccccc}
\hline Day & Pain Scale & \multicolumn{2}{c}{ Before } & \multicolumn{2}{c}{ After } \\
\cline { 3 - 6 } & & \multicolumn{2}{c}{ Respondents } & \multicolumn{2}{c}{ Respondents } \\
\cline { 3 - 6 } & & F & $\%$ & F & $\%$ \\
\hline 1 & No pain 0 & 0 & 0 & 0 & 0 \\
\hline & Lightweight & 15 & 39.5 & 10 & 26.3 \\
& & & & & \\
\hline
\end{tabular}


Ummi Sa'adah : The Effect Of Hatha Yoga on Dysmenorrhoea Pain in Adolescent Principle

\section{$1-3$}

\begin{tabular}{ccccc}
\hline Being 4-6 & 23 & 60.5 & 28 & 73.7 \\
\hline total & 38 & 100 & 38 & 100 \\
\hline No pain 0 & 0 & 0 & 0 & 0 \\
\hline Lightweight & 10 & 26.3 & 13 & 34.2 \\
\hline Being 4-6 & 28 & & & 65.8 \\
\hline total & 38 & 73.7 & 25 & 100 \\
\hline
\end{tabular}

Table 4 Results Statistics Wilcoxon test the pre-test and post-test in the intervention group on Days 1 and 2

\begin{tabular}{ccc}
\hline H -1 & Mean & P-Value \\
\hline Before & 4.24 & 0.000 \\
\hline After -2 & 2.71 & \\
\hline Before & & 0,000 \\
\hline After & 2.71 & \\
\hline
\end{tabular}

Table 5 Results Statistics Wilcoxon test the pre-test and post-test in the control group on Days 1 and 2

\begin{tabular}{|c|c|c|}
\hline $\mathrm{H}-1$ & Mean & P-Value \\
\hline Before & 4.24 & 0.635 \\
\hline After & 4.13 & \\
\hline \multicolumn{3}{|l|}{$\mathrm{H}-2$} \\
\hline Before & 4.13 & 0.102 \\
\hline
\end{tabular}


Ummi Sa'adah : The Effect Of Hatha Yoga on Dysmenorrhoea Pain in Adolescent Principle

After

4.03

Table 7 Mann-Whitney Statistical Test Results Pre-test and Post-test On Group Intervensi and Control group on day 1 and 2

\begin{tabular}{lc}
\hline Group & P-Value \\
\hline Experiment & .000 \\
\hline Control & \\
\hline
\end{tabular}

Based on table 7 above, the results of the P-value of 0,000 obtained indicate that hatha yoga therapy can reduce the pain of dysmenorrhea when compared with the control group. If the conclusion is Ha is accepted which means there is a significant influence before and after the intervention is given.

\section{DISCUSSION}

The results of the research given in the intervention group showed that before and after days 1 and 2 the value of $\mathrm{P}$-value was 0,000 which means $\mathrm{p}<0.05$ so Ha was accepted which meant that there was an influence and there were significant differences between before and after the intervention. This is in accordance with the research conducted by Heni (2012) conducted by experiment on female students at STIKES Ngudi Waluyo and it was found that there was a significant effect between yoga and a decrease in the level of menarche pain. Based on the research that has been done on female student midwives educators at the University of Aisyiyah, that yoga therapy has an influence on the decrease in the level of dysmenorrhoea as evidenced by the results of non-parametric statistical tests with the Wilcoxon technique obtained $\mathrm{p}$-value 0,000 . It can be concluded that value $\mathrm{P}$ - value $<0.05$ which means there is an influence of yoga therapy on the level of dysmenorrhoea (Aisyiyah, 2017).

Other research conducted by Unniraman, Chandran, and Unnikrishnan (2015), states that the effects of practicing yoga can reduce menstrual-related problems, such as absent from school, bleeding, muscle cramps, abdominal pain, leg or back pain, nausea, anxiety, anger, fatigue, diarrhea, etc. in young women. In the second study conducted by Tejwani and Tejwani (2015), states that yoga can be used for the treatment and prevention of menstrual problems ( Lisna Karomah, 2016 ) 
Ummi Sa'adah : The Effect Of Hatha Yoga on Dysmenorrhoea Pain in Adolescent Principle

The researcher said that with the treatment of hatha yoga for the pain of dysmenorrhoea can increase bendorphin levels four to five times inside blood. When someone does hatha yoga therapy, b-endorphin will come out and be caught by receptors in the hypothalamus and limbic system which functions to regulate emotions. Increased b - endorphins have been shown to be closely related to decreased pain in dysmenorrhoea. So it can be concluded that hatha yoga therapy is very effective in reducing the problem of pain, especially pain, dysmenorrhea.

The resulting research given in the control group showed that before and after the control group at day 1 and 2 obtained the value of the P-value of 0635 on the first day and 0102 on day two significant $p>0.05$ then the conclusion Ha rejected which means there is no significant influence before and after observation in the control group.

This is supported by the research conducted by Melda Friska Manurung. It is known that the average pain intensity of dysmenorrhea in the experimental group after being given treatment was 4.20 with a standard deviation of 0.41 . While the average pain intensity of dysmenorrhea in the control group after being given no treatment was 5.20 with a deviation of 0.56 . So it can be concluded that there is no difference between before and after observation of decreased dysmenorrhoea pain with a P-Value value of 5.20 in the control group ( Melda Friska Manurung, 2015 ).

The result of dysmenorrhea is that it can make concentration decrease, there is no motivation for school, cannot learn optimally, and even some are forced to leave class because they cannot stand the menstrual pain that is felt. Especially for people who have to work in a state of illness. All these things are very disturbing and make the body feel uncomfortable, it can even reduce work productivity (Wulandari, 2017).

Researchers also found the phenomenon in the control group that some had decreased pain in dysmenorrhea without Hatha yoga therapy. Respondents said only ordinary relaxation to reduce the pain. But some in the control group experienced an increase in the pain scale. Because there is no Hatha yoga therapy. It can be concluded that there was no significant influence before and after observation in the control group.

The conclusion of this study is that $\mathrm{Ha}$ is accepted which means there is an influence and there are significant differences between before and after the intervention. Whereas in the control group Ha was 
Ummi Sa'adah : The Effect Of Hatha Yoga on Dysmenorrhoea Pain in Adolescent Principle

rejected, which means there was no significant influence before and after observation in the control group.

Based on the research conducted by Nyna Puspita Ningrum (2017), it was shown that of the 32 respondents in this study respondent who had reduced menstrual pain intensity were 15 respondents by carrying out yoga, 10 respondents by implementing dysmenorrhea exercise. While respondent with the intensity of menstrual pain remained as much as 1 respondent by carrying out yoga and 6 respondents by implementing dysmenorrhea gymnastics. After doing statistical tests on the cross-tabulation above using the Chi-square test method, namely "yoga is more effective than dysmenorrhea in reducing complaints of menstrual pain (dysmenorrhea) in Unipa Surabaya midwifery study students" ( Nyna Puspita, 2017 ) .

Another study that supports this research is the research conducted by Kartika (2012) about the decrease in the level of dysmenorrhea in UNPAD Nursing Faculty students using yoga. The study was conducted on 20 respondents. The results show that respondents experienced a decrease in pain intensity $(\mathrm{p}$-value $=$ 0,000). ( Melda Friska Manurung, 2015 ) .

The results of other studies say about the difference in influence before and after yoga on the level of dysmenorrhea shows that there is an influence of yoga on the level of dysmenorrhea. The mean (pain) intensity of pain before yoga is 4.48 and the average pain intensity after yoga is 1.91 . This happens when pain is subjective and only someone who experiences the condition can describe the amount of pain that is felt. So that it will affect the decrease in pain intensity score in each respondent ( Kartika Siahaan, 2012).

Muscle spasm can cause pain during menstruation. Pain is caused by the influence of muscle spasm that compresses blood vessels and causes ischemia. Pain due to tissue ischemia occurs when blood flow to the tissue is blocked. This occurs because of the accumulation of large amounts of lactic acid in tissues formed by anaerobic metabolism, there may also be other chemicals such as bradykinin, prostaglandins and proteolytic enzymes that form in tissues due to cell damage. These ingredients and lactic acid will stimulate pain nerve endings ( Guyton, 2006).

Yoga is a type of relaxation technique that can reduce pain intensity. Yoga is very useful to relax the skeletal muscles that experience spasm caused by an increase in prostaglandin so that vasodilation occurs in the blood vessels and will increase blood flow to areas that experience spasm and ischemia ( Smeltzer \& Brenda. 2002). 
Ummi Sa'adah : The Effect Of Hatha Yoga on Dysmenorrhoea Pain in Adolescent Principle

The results of this study indicate that in comparison to the average pain scale of dysmenorrhoea before and after the experimental and control groups there were significant differences, it can be seen in the second P-Value of the research groups that the probability value in this study is $\rho=0.000$ in the group dysmenorrhoea pain $(\alpha=<0.05)$, the conclusion is that Ha is accepted and H 0 is rejected, which means there is a significant difference between the experimental group and the control group in adolescents who experience pain dysmenorrhea in Darul Falah female boarding school.

\section{CONCLUSION}

It has a different scale of pain before and after intervention in the experimental group in this case because hatha yoga can produce the hormone endorphin and this hormone functions as a natural sedative that creates a sense of comfort and reduce pain. There are differences in the effect of hatha yoga therapy on changes in pain in dysmenorrhea in the experimental group and the control group.

This study is expected to be taken into consideration in providing treatment for dysmenorrhoea treatment, so as to minimize the use of pharmacological drugs that have contraindications so that ascertainment of hatha yoga therapy can be used as another alternative in the management of non-pharmacological pain in dysmenorrheal.

\section{REFERENCES}

Aini, F., Putu, L., Septi, D., Kd, D., Novitasari, D., \& Kunci, K. (2016). Pengaruh Senam Yoga terhadap Tingkat Stres pada Remaja dalam Persiapan Menghadapi Ujian Nasional. STIKES Ngudi Waluyp Ungaran Jl.Gedongsongo Candirejo Ungaran Barat, IX(2).

Aisyiyah, D. I. U. (2017). Pengaruh Terapi Yoga Terhadap Tingkat Dismenorea Pada Mahasiswi Bidan Pendidik.

Bash, E. (2015). Pengetahuan Menstruasi Remaja Yang Mengalami Substitusi Pola Asuh Pada Keluarga Tki. PhD Proposal, 1(2012), 1-8. https://doi.org/10.1017/CBO9781107415324.004

Dewi, A. M. (2015). Pengaruh Gerakan Yoga Terhadap Penurunan Nyeri Dismenore Pada Siswi Smp AlFattah Semarang.

Eka Yuli Handayani, A. syahadat. (2018). Pencegahan Nyeri Haid Melalui Pemanfaatan Terapi NonFarmakologi Pada Remaja Putri Sman I Tambusai

Guyton, A.C \& Hall, J.E. 2006. Buku Ajar Fisiologi Kedokteran. Jakarta: EGC. 
Ummi Sa'adah : The Effect Of Hatha Yoga on Dysmenorrhoea Pain in Adolescent Principle

Handono Fatkhur Rahman, dkk, 2018, Pengaruh Terapi Dzikir terhadap Dismenorea Primer pada Remaja Putri. Jurnal Sain Med, Vol. 10. No. 1 (Juni): 17

Inggriani, P. (2017). Pengaruh Hatha Yoga Terhadap Penurunan Dismenore Pada Mahasiswi Fakultas Keperawatan Universitas Katolik Widya Mandala Surabaya. Jurnal Universitas Katolik, 1, 1-125.

Kartika Siahaan, 2012. Penurunan Tingkat Dismenore Pada Mahasiswi Fakultas Ilmu Keperawatan Unpad Dengan Menggunakan Yoga;1-12

Kaszubski, F. \&. (2004). Absolute Beginners Guide to Alternative Medicine. United States of America: Sams Publishing.

Melda Friska Manurung. (2015). Efektivitas Yoga Terhadap NyeriDismenorePadaRemaja, Jom Vol. 2 No. 2, Oktober ;1262

Nyna Puspita N, 2017, Efektifitas Senam Dismenore dan Yoga untuk Mengurangi Dismenore: Global Health Science, vol. 2, issue. 4, (Desember): 329

Ruhi, D., \& Meenal, K. (2014). Prevalence of dysmenorrhea among girl students in a medical college, $4(1), 49-51$.

Sindhu, P. (2009). hidup sehat dan seimbang dengan yoga:daily practice. bandung: Qonita.

Sindhu, P. (2014), yoga untuk kehamilan edisi yang di perkaya sehaat, bahagia, penuh makna. bandung: PT mizan pustaka.

Smeltzer \& Brenda. 2002. Buku Ajar Keperawatan Medikal Bedah Brunner \& Suddarth vol. 1. Jakarta: EGC.

Solihatunisa, I. (2012). Pengaruh Senam Terhadap Penurunan Intensitas Nyeri Saat Dismenore Pada Mahasiswi Program Studi Ilmu Keperawatan UIN Syarif Hidayatullah Jakarta.

Wulandari, S., \& Afriliana, F. D. (2017). The Effect of Consumption Dark Chocolate Against Primary Dismenore Pain for Girls Teenager at Kediri 5 High School. Indian Journal of Medical Specialities, 4(February), 17-24. https://doi.org/10.5281/zenodo.272645. 